\author{
University of Delaware \\ Disaster Research Center \\ PRELIMINARY PAPER \#50 \\ THE VAIONT DAM OVERFLOW: \\ A CASE STUDY OF EXTRA-COMMUNITY \\ RESPONSES IN MASSIVE DISASTERS \\ E. L. Quarantelli
}

1978 
How do organized elements of social systems respond when component sub-units such as communities are devastated? That is, on what do extra-comunity agencies and organizations focus, to what do they give priority, where do problems arise, and how are they solved when a particular geographic area undergoes massive destruction of 1 ife and property as a result of a sudden catastrophe? If it is true that the structure and functioning of social systens, as well as of individuals, can be more clearly discerned in extrene situations, knowledge of actual group responses in such situations should contribute to an understanding of the fundanentals of social life. What is ignored and what is singled out when groups from non-impacted areas converge on a destroyed community? Where are the sources of the problens encountered by converging organizations; how do they handle their difficulties?

In most disasters, such questions are difficult to study because extra-commity organizational activity is so heavily intertwined with the emergency responses of groups within the stricken locality. Even the analytical separation of the blend of activities as well as of problens is a formidable task in such situations. Only in instances of a massive cataclysa is it possible to examine the questions in relatively pristine form. Of course, if loss of life and denolishment of property is all but total as in the Mt. Pelee volcanic eruptions involving St. Pierre, Martinique, there is little of soctological inport to study. Thus, what is required for examination are disasters in which the residents and/or the material aspects of the commuity are massively impacted but not totally destroyed. The two dinensions of people and things are not completely correlated. An epidenic or plague could wipe out all hunan beings in a locality without directly affecting property. There could be evacuation of all persons before a fishing village slid into the sea.

Cases of partial but nassive and sudden destruction of comanities, even apart from wartine situations such as Coventry, Dresden or Hiroshima, are not difficult to find. There is a world-wide and historically fanous list which includes good illustrations of such catastrophes. It ranges from the volcanic eruption of Mt. Vesuvius which destroyed Pompeil to the devastating earthquake which leveled Tangshan, China,just a few years ago. Within the United States, there is the 1871 Chicago fire to the more recent Buffalo Creek, West Virginia flood dan disaster of 1972. The agent can be natural as in the case of the Galveston hurricane of 1900 or nore attributable to hunan factors as in the 1917 Halifax, Canada explosion. In all of these instances as well as nany others which could be cited such as Skopje, Texas City, Messina or Johnstown, there were substantial losses in lives as well as peavy property destruction in specific conmunities within the impacted zone.

The case detailed in this article is an almost perfect nicrocosnic example of a partial but sudden massive destruction of a comunity. As described in the following pages, the 1963 Vaiont Dam overflow in Italy devastated the town of Longarone and surrounding hawlets, killing most of the inhabitants and literally sweeping away much of the material structure and natural features of the community. However, there were residents of the area who survived, and the physical setting could neither be abandoned nor ignored. What extracommunity organizations did and how they responded to this situation is described and analyzed in this paper. 
Our observations and findings are prinarily drawn fron the field work of the Disaster Research Center (DRC) at The Ohio State University, which sent a research tean to Italy within 48 hours of the catastrophe. 2 The information obtained by this tean was later supplemented by other field data and documents gathered for DRC by Italian social scientists in Rone and at the site of the catastrophe itself. While the DRC research covered different aspects of the disaster response over an extended period of time, this paper focuses primarily on the responses of the najor extra-connunity organizations in the first several days after the disaster. ${ }^{3}$ In the pages that follow, we describe the disaster setting and disaster itself and then turn to an account of the inmediate post-impact responses of the major organizations involved. Using this case study, the last half of the paper analyzes the factors affecting extra-comunity organizations activities in massive disasters and some of the consequences of such kinds of reactions. 4

\section{The Disaster Setting}

The disaster occurred in the Fiave River Valley. The Piave River is a 137 mile long river in the extreme northeast corner of Italy, whose source is near the Austrian border. It winds its way through the Venetian Alps, and finally energes onto the plains about 25 miles northeast of Venice before flowing into the Adriatic Sea. About a third of the way down fron the source, in a narrow two mile wide river valley ringed by mountain peaks 6,000 to 8,000 feet high, is a cluster of villages and small hamlets. Six of these are organized into the comrane (i.e., parish or township) of Longarone. Including nearby villages approximately $6,000-7,000$ people reside in the area. Belluno, the capital of the province with a population of over 10,000 , is less than 10 miles downstrean in the valley.

of ancient origin, Longarone is basically a popular mountain resort, and heavily dependent on sumner tourists for its livelihood. According to the census, the population of the conmune in 1962 was 4,636 . However, this is undoubtedly an inflated figure, especially during the non-tourist season, since it is traditional for many of the townspeople to work as raigrant laborers elsewhere in Italy, and even in Switzerland, Austria, and Germany. Although there is no way of ascertaining the actual figure, it is probable that there were no more than 3,500 persons in the commune the night of the disaster.

Directly east of Longarone, about a mile and a half across the valley and at right angles to it, is a gorge. A little back in the gorge is the Vaiont Dam, the highest valut and the second highest dan in the world. It was built to provide hydro-electric power. At a height of 265 meters or 873 feet, the dam overlooks Longarone on the opposite bank of the shallow Piave River. Behind the dan is an artificial lake or reservoir over seven kilometers or four miles long and approximately 400 meters or a third-of-anile wide. Around its shore are about half a dozen hanlets. Directly to the south and towering over the artificial lake is Mt. Toc, 1,821 meters or 6,366 feet high peak.

The darn, discussed for nearly twenty years, was started in 1956 . It had been controversial fron the beginning. Considerable local opposition to its 
building was voiced, especially by the inhabitants of the localities around the artificial lake that was to be created. Their objections derived fron anxieties provided by the ninor rock slides which regularly tumbled down Mt. Toc. The villagers thought that such slides into an artificial lake might endanger their homes and places of work.

Objections continued and became even more widespread as the structure was being built. In 1959 the Comnunist Party paper, L'Unita, raised questions about the safety of the dan. It published an article saying recurrent landslides nade a disaster likely. This led to legal action against the newspaper for the diffusion of false news and disturbance of the peace, but the newspaper was acquitted of the charges.

Even after the dam was completed in 1960, controversy continued. Although construction had been undertaken by a private company, the facilities and their operation were nationalized shortly before the disaster. That action in itself proved controversial, and generated further discussions in the press about safety.

In the months preceding the disaster, concern among the villagers living around the artificial lake mounted, since the slides increased in intensity although none assumed major proportions. After the catastrophe it was even alleged that for several days prior to the event, farm aninals evoided grazing on the slopes of Mt. Toc and were far nore restless than usual. This was not attributed to any nysterious instinct, but simply that aninals are just nore sensitive to earth novenents, and that the incessant rumblings of the constant snall slides disturbed then. Whatever cues people were responding to, concern developed. Several days before the disaster, torrential rains caused enough sliding so that the mayor of Erto, a village of 1,000 people on the lake and alongside Mt. Toc, issued a manifesto urging the villagers to evacuate. He also denanded that the authorities empty the reservoir as quickly as possible. He was supported by the Prefect at Belluno. Apparently, a few howes were evacuated on the lake shore and in the valley below. However, there was not any major concern.

From the time of the first objections, engineers had surveyed and resurveyed the possible danger of a landsilde affecting the water level so as to partially inundace the hamlets and villages around the reservoir lake. It appears that the possibility of any water overflowing or breaking through the dan wall it itself, nearly 39 feet thick at the base and 10 feet at the rim, to the valley below was not considered. Furthermore, it was not until after the dan was completed in July, 1963, that there appeared any visible signs of potentially serlous land slippages into the lake.

At the end of September, three engineer-geologists foresaw, as a result of their calculations, the high probability of an avalanche at the end of November. Some thought was given to emptying the reservoir of all the water, but it was decided that the pressure of the water itself would keep any caving-in of the land from the mountain side within tolerable linits. However, in early october, supposediy in order to insure that there would be no damage 
to lake localities from even a najor slide, the water level in the reservoir was lowered to 65 feet below maximun. This was the situation on the night of October 9 .

\section{The Disaster}

Around 10:40 P.M. on October 9, an enornous nass of earth fell from Mt. Toc and suddenly slid into the lake behind the dan. The physical impact was nassive, being recorded on seismographs in Base1, Switzerland, Trieste and as far away as Rome and Strasbourg in Gemany. A preliminary official estimate offered to the Italian Parliament was that the land slide was two and a half kilometers wide (about $a$ mile and $a$ half) and that its volune was between 200-400 million cubic meters (around 262-523 million cubic yards). When this landslide plunneted into the lake, it produced a great wave of water which crested at last 325 feet over the top of 873 foot dan wall. It was later estinated that over 100 million tons of water were suddenly sent shooting over the wall.

Part of the lake water, of course, backed up in the reservoir and engulfed the lowest reaches of the villages on its shore. Most of the water forced aside by the landslide vaulted high over the dan wall and cane smashing down into the river valley. Longarone was hit at 10:43 P.M. and in a very few minutes was alnost completely destroyed along with the nearby hamlets. As can be seen in before-and-after photographs of Longarone, the tide of water crushed everything in its path in a rather clean fashion. The beach-like appearance of the lendscape in the post-impact period was not the result of any debris clearance activity after the event. The leveling of the buildings and of the topography resulted solely from the action of the water.

Hundreds of houses, factories, fifteen bars and cafes, three bridges, several miles of railroad tracks and the state highway, a large wooded area, etc., were leveled and obliterated. "Ground zero" was just at the western edge of Longarone. For a radius of almost two miles across and about four miles up and down the valley, the destruction was all but total. Even six days after the impact it was difficult to find any physical sign or feature that a community once existed on what now had the appearance of a very wide but dry river bed, nostly covered with snal1, round pebbles. The chief exception to this was a handful of only slightly water-danaged houses at the northwestern edge of the devastated, but razed area. This was the tiny section of Longarone on which the nass of water did not land, in part because it was somewhat up the slope. In this cluster of houses, including the town hall, lived most of the 79 inhabitants of longarone who were not casualties of the disaster.

Sone of the water spreading voiding out into the valley spilled a little northward, sideswiping several hamlets and villages in the process; but most. af it emptied southward and down river. Because of the width of the valley and the river bed itself, the tide subsided relatively quickly in height and width once it had moved three or four miles downstreani from the edge of the impact zone. The level of the Piave River did rise almost 15 feet at Belluno, nearly ten miles south, to danage nore than 150 houses along the shore line. However, the river dikes in most places prevented spillege into built-up areas. 
In the impacted areas below the dam and around the lake nost victims apparent1y had little, if any warning; nany, in fact, were caught in bed asleep. As one survivor reported:

I was awakened by a noise sinilar to that of jet planes very near. A great wind entered ny house, smashing in doors and windows, blowing everything away. Then I saw a thick haze preceding a huge wave of water which spleshed my house, carrying away ny nejghbor's. I thought it was a tidal wave coning out of nowhere (Besson, 1966: 24)

In Longarone alone, 1,269 out of 1,348 persons, known to be in the town at the tine, were killed. At least 158 died in Erto and Casso, villages located on the reservoir. A mininum of 569 other persons in other localities in the commune were also fatal casualties. In the downriver valley area there were few casualties, even where there was substantial property damage.

Thus, three different areas felt the inpact: Longarone and the immediately surrounding circle of hamlets where the physical destruction was all but total; the villages on the shore of the reservoir where the danage was extensive although far from complete; and the hamlets and towns, starting four or five miles down the river valley where the naterial damage ranged from fairly substantial to inconsequential.

\section{Organizational Responses}

Surrounding areas not within visual distance of the impact zone becare aware that sonething was amiss through several often intermixed cues. The electric current went out in sone nearby localities, there was a tremendous roar in the distance, and those persons downstream ncar the Piave saw and heard the rapid enlargenent of the river. In addition, a few individuals at the edge of the devastated zone comprehended something of a disastrous nature had occurred, and started to telephone such outlying fire, police, and civil authorities as could be reached. At the time of the overflow, the head of the carabinieri (i.e. national police) was by chance talking on the phone to a colleague at the carabinieri post at Fonte Nell'Alpi, five niles south. Before the line went dead, the caller at Longarone managed to communicate that there was a strange noise and that he was in very great personal danger.

None of the early cues obtained outside the stricken cominity clearly indicated what had happened. There were minutes of confusion as perplexing reports filtered out fron the fringes of the devastated areas to nore distant localities, and as river residents increasingly called in about the unusual behavior of the Piave. Efforts, of course, were made to contact Longarone and imnediately surrounding localities but these obviously evoked no response.

By piecing together the early sketchy and sometimes incoherent reports, the officials, initially contacted, relatively quickly defined the situation as somehow involving the Vaiont Dam. In general, the opinion was that the dam must have collapsed or cracked, and to an unknown degree, affected the areas 
below. No one at that titne seems to have considered the possibility of any difficulties around the reservoir itself.

Generally speaking, the early reports and sightings primarily activated four different extra-community groups in the region: police and fire organizations, the military, and the civil authorities. The next section of this paper generally describes the alerting, mobilization, and actions of these organizations in the imnediate post-impact period.

The Immediate Post-Impact Period

Fire Organizations.

The first direct response by any organization was by the firemen at Belluno. Less than five minutes after the disaster occurred, a private citizen at Ponte Ne11' Alpi called the fire brigade operator at Belluno. The caller indicated that not only had there been a big roar followed by a black-out of the electricity north of the town, but that now the river was full of debris and rising rapidly. The telephone operator surmised from this that the vaiont Dar had been blown up. (Prior to the disaster terrorists agitating for the reunion of a part of Italy to Austria had been planting borabs for several months in many parts of northern Italy, see Doob, 1962). After failing to get through to the fire group at Longarone, the operator called and alerted the carabinieri in the area, police headquarters, the commune police, the Conmandant of the Cadore Brigade of the Italian Array based in the zone, the police at Feltre and the civil engineer. Since the Commandant was out of town, the Vice Conmander of the fire brigade took charge of the mobilization of fire personnel.

Three firemen were sent to the lower reaches of Belluno and to those parts of the city along the river in order to warn the restdents of possible flooding. The DRC data does not clearly indicate who initiated this action, or at what exact time it was undertaken. However, the warning was initiated relatively soon after the first call.

Since inconing reports to Belluno continued to be confused, the firemen dispatched a truck with four men to make a reconnaissance in the direction of Longarone. While noving north this group at about 11:15 eventually found that they could not continue to drive on the road as it was totally washed out by the Piave River which had overrun its banks. These firemen did save two families who had taken refuge on the roofs of their engulfed houses. The firemen also saw near Ponte Ne11: Alpi the first of many cadavers being carried by the Piave. On the basis of these sightings, and the maze of debris in the agitated river they reported to Belluno that Longarone, at least, had probably been destroyed.

During the same time period and in about the same way, fire groups in the valley north of the stricken area also began to nove toward Longarone. They had an advantage in that there were no washed out roads or debris in their path. On the other hand, since the river was quite normal in their area, 
it took then longer to realize that sonething was amiss than the groups south of Longarone. Whereas elements of the southern fire groups had pushed to the edge of the inpact zone and had rescued survivors on the fringe within 45 minutes of the overflow, it was over an hour before the first units of firemen coming from Pieve de Cadore (a few miles north of Longarone) got to the disaster site. This group of firemen rescued several dozen injured survivors.

Meanwhile at Belluno nore and more distant fixe organizations were alerted, The firemen at Treviso were telephoned; they, in turn, notified venice about the probability of a major catastrophe. The Belluno Vice-Commander also called the Director General of the Anti-Incendiary Services at the Ministry of Interior in Rome. This call went through before midnight and caused the National Corps of Firemen to activate its plan for major disaster relief.

In addition, after the reconnaissance, other reports, and continuing calls, the magnitude of the disaster became somewhat more apparent although far from clear the fire organizations in Belluno mobilized its 60 men supplemented by 370 volunteers and sent them northward into the impact area. The major task was that of searching for possible survivors. The field conditions for operating at midnight were very difficult. Mobile equipment could only be brought up so far because of the blocked roads and destroyed bridges as well as the fact that the impact area was a sea of nur, sline, and water. Almost all natural and topographical points of reference on the ground had been razed. Of course, no lights were available. The extent, direction, and limits of the physical devastation literally had to be discovered foot by foot. The magnitude of the difficulties in moving about was indicated by the fact that it was nearly five and one-half hours after the tidal overflow befor the firemen moving down the vally finally encountered, in the middle of what once had been Longarone, those fire units coning up fron Belluno.

Although details of the situation on the scene remained unclear to the outside world for hours - it was not until morning, for example, that it was discovered that the dan wall itself was still standing -- more and more fire groups from further and further outlying areas converged on the inpact zone. Ful1 fire detachments from sectors west and north of the inpact area had arrived around midnight. By five o'clock in the rorning, columns from other fire departments of the province reached the scene. At that time also the Inspector General of Zone III of the Fire Services arrived from Venice and took charge of the operations being conducted by the fire teans.

By dawn between 400-500 firemen had converged on the scene. It was only at this time that any sort of coordination as well as overall control was developed arnong the nultiple fire detachments. The decision was also made then that the firemen would concentrate their efforts on the southern part of the affected area. This was chiefly dictated by the fact that the fire units assumed, as part of their usual emergency tasks, the prime responsibility of searching for bodies, and victims, of course, would be more likely to be found downriver. 
Police Organizations.

As already indicated, a carabinieri post downstream was actually in contact with an officer at Longarone at the time when the water smashed into the town. However, the headquarters at Belluno was first notified of a possible disaster by the fire brigade telephone operator at Belluno. This information was given to the second-in-command, a Captain who had gone to headquarters since the comnandant of the carabinieri was out of the city. The Captain, after phoning the Prefect, inmediately drove towards Longarone. He found, as did others, that the road was blocked several miles south of the town. He, therefore, left a man there with orders to block the entry of anyone not engaged in rescue activity and then returned to Belluno.

At headquarters, the Captain devised a plan of operation, divided his carabinies into squads, and sent them to the disaster area. However, carabinierf with firemen coning down the valley from Pieve del Cadore actually reached Longarone before those sent from the south. The police, of course, encountered the same problems in moving about as did the firemen.

In the early hours the carabinieri primarily worked at opening passages in the debris, providing assistance in renoving the few survivors, and recovering victims. It was not until morning, however, that a procedure was initiated by which the squads could systematically search the inpacted area for victims. At laybreak it was fully realized that there were only bodies to be recovered and no survivors. It was also at dawn that the comanding colone 1 of the Legion of Bolzano arrived and took charge of overall carabinieri activities which by then involved hundreds of officers.

Although sone highway and comnunal police may have participated in the first attempts at traffic control the night of the disaster, police units other than the carabinieri appeared to have taken a rather minimal part in the early disaster operations.

\section{Military Organizations.}

In accordance with the fairly standard procedure followed in Italy upon news of the disaster, the office of the Prefect notified the nearest Italian military conmand which was also in Belluno. This was around midnight. Thus, the nearest army unit did not learn of the disaster until more than an hour after its occurrence. When the commanding general of the brigade at Belluno was alerted, he started to mobilize various military components under his command. Lacking specific information, but having no doubt that a major disaster of come kind had occurred, he telephoned a battalion stationed in the Piave River valley 14 miles north of the dan area and a Belluno-based engineering company. These units were ordered to proceed into the blacked-out area and to ascertain what had occurred. Under the commen of the colonel of the 6 th reginent of the brigade they had instructions to render what assistance they could.

The military columns, one coming from the north and the other from the south, laboriously worked their way through the debris in the impact zone. The two 
columns met near what had been the center of Longarone sometime after 2:00 A.M., making a somewhat earlier juncture than had the firemen. During the night the units on the disaster scene were reinforced by another battalion and an artillei company from Belluno. By 5:30 A.M. there were at least 1,200 soldiers in and around Longarone.

Even as the initial units were starting to move into the stricken area, news about the disaster was being transmitted to wore and more distant military groups. By 1:00 A.M. the brigade commander at Belluno alerted the III, IV, and $V$ Italian Army Corps Headquarters, the Regional Command at Padua, and had established direct commication with the Military High Command in Rome. A little later he also contacted the American base at Verona.

During the night, the soldiers on the scene primarily searched for survivors in a rather trial-and-error fashion. Seemingly, they did not coordinate their activity with the firemen's earlier efforts. The soliders also helped to evacuate sone of the victins, carrying then to the northern edge of the disaster zone and then driving then in army ambulances to hospitals. Although Belluno had the nearest hospital, the victims had to be taken north because the valley area south of Longarone was the most devastated and impassable for traffic. The military found several dozen injured survivors.

Systematic search procedures and overall coordination of activity was not initiated until dawn. At that time the northern part of the devastated area was divided into three sectors and assigned to three different ailitary units for searching. Around 3:00 A.M. the three-star general in comnand of the region arrived on the scene and assumed the direction of all military activity in the area.

Civil Authorities.

The civil authorities in Belluno had been alexted by the carabinieri captain. The initial information they received was that some sort of disaster had occurred upriver and that most likely the Vaiont Dan had broken. Led by the Prefect a group attempted to go up the river valley. They soon discovered that the state highway was blocked by debris about five miles south of Longarone. This group backtracked, came around in a very wide circle, and tried to enter the valley are from the noth where several hours later they encountered a similar scene of destruction. If nothing else, this sweeping notor reconnaissance enabled them to estimate correctly the geographic extent of the hardest hit area. Actually, prior to this latter trip, the civil authorities at Belluno had already been briefed at 3:00 A.M. by the Colonel of the 6 th Regiment who had penetrated the impact area, and had reported his observations. The Prefect eventually got penetratedthe Longarone area about $6: 30$ in the morning.

Initially, the top officials of organizations outside of the impact area, unaware of what had happened but knowing something had, began to notify and mobilize their own supporting units and other organizations. Thus, around 1:30 A.M. the civil authorities remaining in Belluno had alerted seven hospital; in the surrounding cities that their facilities might be urgently needed. Following a 1927 law, they also notifled the appropriate governmental ministrie! in Rome of the probable disaster. The chief medical officer of the province, 
for instance, reached the Health Minister in Rome around 2:00 A.M., about three hours after the catastrophe. These alerts led to the mobilization of different units so that by morning, organizations from a distance had started to move in the direction of the stricken area (e.g. American helicopters flew out from their base at Verona at 5:10 A.M., a battalion of Alpi : troops left their base at Feltre and proceeded to Belluno, etc.).

\section{Secondary Threats}

In part, the four organizational responses just discussed have been treated separately because the initial reaction, despite some communication, was by relatively autonomous groups. At the formal level at least, they all worked rather independently of one another. For example, each organization sent a reconnaissance unit up the road with each discovering on their own that it was blocked. With dawn the situation began to change, and there was a more coordinated response to secondary threats.

From a number of 1,200 early the morning after the disaster, the Italian Army contingents rose to a total of 4,000 later that day, eventually reaching 5,000 and dropping off to 2,900 by Monday, the fourth day. Since the Arny units constituted the bulk of the organizational personnel in the impact area, it is doubtful that disaster workers ever numbered 10,000 as journalistic reports stated. To be sure, there were other military elements operative such as the already mentioned American 110 Aviation Company from SETAF in Verona and to a lesser extent American engineering units fron Vicenza. Besides the local and regional civil authorities there were also such civilian organizations as the Italian Red Cross, a Salvation Arry unit from Rome, a disaster agency of the Vatican, helicopters with Swiss engineers and nountain climbers, and even French and Yugoslavian teams who specialized in identifying the dead. Several days after the disaster, other governmental groups appeared, e.g., the GDF (Treasury agents) who guarded the vaults of buried banks, and railroad workers from Venice who started to restore the rail line. Still it was IV Italian Army Corps which provided the core as well as the coorlination of all organizational activities in the stricken area. Most of the police forces, carabinieri, automatically came under Army control.

There were some secondary threats perceived after the initial disaster. These varied somewhat with the three different areas that had been impacted. In actuality, these threats were either nonexistent or really very remote. Sti11, from the standpoint of many inhabitants and/or sone organizational units, secondary potential threats were perceived.

The dan wall itself, despite the tremendous pressure when the water crested over it, remained intact. In the days following the disaster there was a fear that the dam would give way, especially since anyone could readily see the large land mass that had slid into the reservoir lake towering several hundred feet alnost immediately behind the dam wall. This concern was reinforced by newspaper headlines proclaiming such a danger. Actually, engineers had inspected the dam wall and found it fundanentally sound. As an additional precaution, however, an around-the-clock photoelectric systen which would signal any shifts in pressure was installed. This was generally unknown to 
people in the valley, although communicated to the higher echelons of the Italian Army. Thus, on Sunday night, four days after the disaster, as a result of the wailing siren of a fire truck on its way to answering an alarn for an ordinary small fire, precipitous flight occurred anong some survivors in a few of the partially damaged localities near the rim of the major impact area. The Italian Army eventually stationed Alpine troops in all the alarmed villages and towns in an attempt to reassure the populace there was no danger from a dan break.

There was also a widely expressed concern, especially by the press, over the possible threat of an epideric as a result of the large number of dead bodies. Some even saw a potential threat to cities more than 60 miles downstream which were finding dead bodies in their sections of the $F$ iave River three days after the disaster. The medical authorities never defined a potential epidemic as too likely. They did, however, undertake an extensive chlorine decontamination of the devastated area. This was undertaken manually by soldiers, and to a certain extent by the use of helicopters and special trucks sent from Padua. Apart fron this precautionary activity, the threat was discounted in part because the bodies closest to the surface were rather quickly recovered, whereas those deeply buried under feet of earth and rock were by that very fact not 1ikely to become easy sources of infection. As of Tuesday, October 15, at least 1,500 bodies had not yet been found. Animal carcasses also were plentiful but those that were readily recoverable were disposed of by Italian Arny units who used flame throwers or buried the animals in pits of lime.

For a while,too, there was some concern on the part of public health organizations that the river water night have been poisoned. The newspapers also played up this threat. A lumber factory near Longarone, which stores large druns of potassiun cyanide weighing thousands of pound was demolished. The drums were presuned to have been carried downstream. The possible although renote danger was that a concentrated dosage of the contents of the drums might get into the water supply of such cities as Venice and Treviso which drew part of their water from the Piave River. Thus, this potential danger was not seen as existing in the impact area, but in a "fallout" region considerably further downriver. Initially, a daily chemical analysis was made of the various water supplies with negative results. By the fifth day after impact, eight of the drums had been recovered frora the river, six of then still intact, thus removing even the remote threat.

A secondary threat was also perceived in the nountain villages and hamlets around the dam reservoir. In the first place, these localities were partially isolated. The main paved road fron the river valley into the mountains had gone directly over the dan rin and thus had been swept away. While Italian army engineers were able to construct a new paved road in the river valley by Sunday, they were unable to reconstruct a new road up the mountain side as quickly. This left only a very circuitous and secondary nountain road for entry into the lakesibe area when coming from the east. In fact, without the direct road it was necessary to go over 100 kiloneters to get fron Erto to Longarone. Thus, there was a problem of maintaining comunication with the mountain villages and keeping them supplied with the normal provisions. The 
latter was finally accomplished mostly through the use of large United States Arny helicopters which took food supplies from the Italian supply depot at Belluno and also brought in drinking water.

In addition, some responsible authorities felt that eertain hamlets and village: on the reservoir should be evacuated. The concern was that the continual backing up of water behind the land mass that had slid in behind the dam might undermine the already damaged localities on the lake shore. Casso, with a population of 450 , for instance, was considered to be in danger of sliding into the Vaiont reservoir. Thus, an evacuation of Casso, Erto, and San Martino was ordered by the carabinieri. The inhabitants were helicoptered out despite their objections over being forced to leave, a frequently noted phenomena in disasters (Moore, 1963). Some of them, in fact, returned at night and had to be re-evacuated again the following day. Carabinieri patrols of ten men were then left as guards in each village.

\section{Some Observations}

1. There was an extremely high ratio of killed to injured probably in the rane of 40 dead for every nonfatal casualty. Even in absolute numbers there were only three or four score injured. This had numerous consequences for postdisaster operations. Among the consequences were intra- and inter-organizatior. strains 5 and public criticism of organizational activity. These are illustrated in the following examples.

Organizations at a distance and distant higher headquarters of organizations operating in the impact area kept inquiring why the groups on the scene did not request medical supplies, physicians, blankets, bedding, etc. Working with the usual inage of disasters where there are always more injured than dead, they found it difficult to comprehend that in this catastrophe there were almost no survivors. Thus, some outside agencies, whether in ministries in Rome or higher American and Italian military conmands, repeatedly asked in their official communications why certain personnel and supplies were not being requested. Organizational officials on the scene almost seemed to feel they were being accused of dereliction in their responsibilities because they did not make such requests.

Another effect of the high death ratio was that the immediate post-disaster "rescue" operations were slowed down. When the Italian Army ascertained that there were no injured left to rescue, a decision was made not to use heavy equipment. Instead, personnel and shovels were employed in digging for bodies and for debris clearance. In part the military did this because it saw no urgency as would be the case if living victirns had to be excavated. Also, heavy equipment would mangle the cadavers being found. There was, however, much public criticism because the military did not use bulldozers and other engineering equipment. To the critics it simply seemed that the Army was not using the most rapid means available in its "rescue" operations. Partly involved here was the general image people have that disasters are situations in which many people have to be saved. Partly involved also, perhaps, was a failure to communicate adequately and quickly enough the actual casualty picture in this disaster. 
2. The post-disaster emergency operations were overwhelmingly conducted by and focused around the Italian Army. Thus, the vast bulk of the post-disaster field operations from almost their initiation to six days later, were conducted under the general direction and supervision of the military. However, these operations were in the hands of an organization which felt hamstrung by its lack of nominal and legal authority and which never had full control. Also, in the later stages, the operations were being conducted by an organization that felt it had accomplished its tasks and that whatever else needed to be done was really the responsibility of others.

In part the heavy military nature of the operations stenmed from the structure of Italian society. The Arny is the organization which is supposed to operate in such situations. In part, however, the military took such a central role because of the reluctance of the civil authorities (for important reasons to be discussed later) to take a prominent part in post-disaster activities. There is even evidence, for instance, that the prefect, after being on the scene at dawn the morning after the disaster, did not revisit the Longarone area again for four days. More important, requests directed to the civil authorities for information and other matters were turned over to the military command. The implication was clearly left that the Army had full control of the situation on the scene.

Operationally this was the case. However, the Arry denied in statenents issued to the press that it had superseded the civil euthorities. It maintained, and legally and nominally this was certainly the case, that it was always under the control of the civil government. Equally as important, on some crucial matters for its own operations, the Army waited for these authorities to act. A particular case in point was the strong desire of the Arny that the inpact area be blocked off to visitors, sightseers, etc. -- an action however, which the Army overtly defined as a function of the civil government only, but which was never taken. Likewise, the military indicated that it could and would just as soon have withdrawn from the disaster scene as early as Monday morning, Gctober 14. As one high officer said, "Road building is hardly a military function." However, there wer no civil authorities willing to take over the ongoing activities and fill the vacuum in structure if the military pulled out. 6

3. The pre-impact political situation had a strong effect on the post-disaster operations of both. the Italian military and governmental organizations. To understand how this occurred requires knowledge of three facts. Italy is a highly pluralistic society, with political groupings spanning the spectrum from the extreme right to the extreme left. This means that partisans of vast: different political orientation may and do occupy positions within the same as well as different levels of government.

With the disaster, all these political factors cane together. Elected and appointed political officials found themselves faced with the possibility of having to take orders and/or coordinate their actions with other office holders from drastically different political orientations. The Commists immediately recalled to the attention of all that they had predicted a disaster. Opponents and adherents of private enterprise and nationaiization accused the systen 
existing either before or afterward, as being partly to blame for the disaster. In colloquial terns, in light of the pre-disaster situation, the disaster became a "political football", and the blane assessment which follows certain kinds of disasters occurred (Drabek and Quarante11i, 1967).

A major consequence of this was the unwillingness of the civil authorities to make themselves too conspicuous or to appear to be making major decisions in the post-disaster operations. Any reading of the hostile exchanges in the Italian Parlaiment, the observation that the President of Italy himself was greeted by a very hostile crowd when he visited Longarone on Sunday, or the occurrence of several demonostrations elsewhere against the further building of other dams, suggests that a pose of inconspicuousness did not altogether lack a basis in fact. In this vacuum, the military was thrust forward.

However, as indicated earlier, the military did not have full power so there were consequent problems. As some newspapers openly declared -- if the Army disavows having full authority, if the Prefect claims to be at best only a coordinator, if various governmental bureaus state they have only limited technical functions, who is in control? Who is responsible for decisions about evacuation, about proclamations regarding dangers from secondary threats, etc.? Furthernore, while to a certain extent the military could play the role of being an organization above politics, it was not immune to criticisms with political overtones. It too, therefore, was reluctant to take what it considered appropriate actions, e.g., the sealing of the area to outsiders, the cessation of further digging for bodies by the third day, the withdrawing from the scene by the fifth day, etc. Thus, a number of the actions of both the civil authorities and the military cannot be understood except in the context of a predisaster political situation. 7

4. Pre-impact factors, especially certain cultural values and norms, also were very important in how the dead were handled. Some of the values were religious ones but others were not. These values and norms were operative in relation to bodies that were not recovered as well as those recovered. In fact, as of Tuesday afternoon, October 15, the official count of recovered bodies had reached just 1,100 , only a little more than 40 percent of the lost semi-officia: estimates of those killed. For some reason, the press and other organizations consistently tended to use figures about 50 percent higher than the official count.

There was a very high degree of reluctance exhibited to manual handing of the dead bodies. 8 The disaster was not enough to move civilians particularly to such actions radically at variance with pre-disaster expectations. In some instances, for example, men in the area refused requests to aid in the unloading of bodies from helicopters bringing the dead to central collection points until sternly ordered by carabinieri to help in the task. This happened in the first 48 hours before much decomposition of corpes had occurred. The task of handling bodies was eventually turned over to the local fire companies on the grounds that they were experienced in handing the dead. This also was more a cultural expectation of a particular social role than something that was necessarily true of most small-town firemen. 
As indicated, in the early post-disaster days bodies were brought to scattered collection points. It is rather unclear who was responsible and how such points were established. However, this was clearly an improvisation which was not too systematized. There were occasional sudden and unannounced shiftings of the collection points leading to confusion when organizational personnel appeared with a load of bodies at what once had been such a point.

In the first day or so, some sort of mass burial with separate coffins and a common ceremony was contemplated. Who made the suggestion and how it was intended to be implemented again is not clear from the available data. Very clear, however, is that the idea provoked a very strong negative reaction and was quickly abandoned. In part, the opposition came from religious sources. The position was taken that each and every one of the dead were entitled to a separate burial with an individual ceremony, as is the norm in non-disaster situations.

With the abandonment of the mass burial idea, there was a period of confusion of what to do with the constantly accumulating bodies. Undamaged nearby localities objected that their cemeteries simply were not large enough to accomodate the great number of bodies needing burial. The medical officer of the province in cooperation with the civil engineer, therefore, picked out a site for a new cemetery at Fortogna, about a mile and a half north of what had been the center of Longarone. In part, this locality was chosen so as to minimize the distance the bodies had to be transported from the collection points. Once the decision was made, quick action followed. A large grain fleld was expropriated and a religious blessing was prounounced over the location in the course of a few hours. In this, pre-existing legal and religious norms were followed.

However, while the site was quickly chosen, burial of bodies proceeded very slowly, since it was decided that a major effort would be made to identify all bodies. This too stemed from a general expectation that a proper burial required at least an attempt at identification. -Since whole families tended to be killed together and there were few survivors in the area who could identify the dead, this posed further problems. Eventually it was decided to wait for relatives who lived outside the disaster area to come and make identifications. In the instance of those bodies for whom no identification was given by relatives, photographs were taken and numbers assigned so that later identification would be possible.

However, between waiting for relatives to appear and taking photographs, considerable time elapsed before coffins could be sealed and put in the ground. In fact, as of Tuesday, October 15, six days after the disaster, the majority of the coffins were unsealed and above ground at the new cemetery site. This delay in turn evoked strong criticism, especially in the press. objections were raised that this kind of delay was disrespectful of the dead, and that the unsealed coffins might even be a health hazard of some kind. It is fact, incidentally, that on Tuesday an order was given that all the unsealed coffins were to be elevated on bars so as to be at least six inches off the ground. It was said that this would eliminate any possibility of contamination from the corpses, some of whom had been found five or six days earlier. 
Many of the authorities felt that the search for bodies should have been stopped much earlier since any new corpse found would very likely be in a highly deteriorated condition. In fact, on the third day after the disaster organizational personnel were already complaining of the problems involved in handing leaking corpses and bodies whose extremities came off when they were touched. Also as one high ranking officer noted, "It's absurd to dig down ten feet of rocks and stones to find a body so we can re-bury it in only five feet of dirt." Here again, however, the military and other organizations felt considerable pressure to keep searching for bodies. In some respects, this pressure even increased in the later days when distant relatives finally arrived upon the scene and insisted that the search continue for the still unfound bodies of their own families. In this disaster the handling of the dead bodies posed one of the major problems and evoked more criticism than almost anything else connected with the incident.

5. There was almost universal condemnation by other organizational personnel of mass media representatives. Remarks ranged from hostile to vitriolic. Among others, there were charges that many supposedly direct quotations were totally fabricated, charges that official announcements failed to be transmitted, and charges that some of the political press was deliberately agitating the populace to look unfavorably upon the disaster operations of certain organizations. What, if any, validity there was to such accusations is beyond the scope of this study, but the existence of an openly expressed, negative orientation towards mass media reporting was an easily observable fact. It led, in a few instances, to forceful although highly unofficial actions against press representatives in an attempt to restrain their movements in the impact area.

Three conditions seemed to have contributed to the hostility. The attempts by newsmen to obtain information were acknowledged as legitinate, but not when defined as interfering with carrying out organizational objectives. Resentment was especially generated when direct quotes were attributed to officins who never talked to news people. Other people who had spoken to journalines felt they had been badly misquoted. Another point of irritation stemmed repetition of the same questions by various news personnel. The absenc of any central point in the disaster area where information was formally or officially distributed undoubtedly aggravated each of these conditions and led to a certain amount of inaccurate mass media transmissions. 9

6. Different organizations and units within organizations had sharply divergent perceptions of one another's operations. $10^{8}$ In the first place, there was usually a great deal of haziness regarding what other groups did and were doing. For instance, there was an openly admitted lack of clear perception by the Italian military of the operations of most of the civilian, non-governmental organizations such as the Red Cross. There also seemed to be organizational difficulty in understanding the basis for action or lack of it by other organizations as exemplified by some bewilderment regarding why the Italian Army did not impose any control on the traffic into the impact area.

Then too, in some instances, the higher echelons of organizations had limited perception of the potential capacities and actual field operations of their 
subordinate units. More improvisation probably was carried on at lower levels than was at least officially acknowledged. In addition, there was a tendency for units or organizations to judge the effectiveness and rationality of other organizations in terms of the activities that impinged on their own operations. Thus, the smoothness and coordination of operations at liaison points was a criterion by which other organizations were judged. This was fairly apparent in how the American military units evaluated the operations of the Italian military in the disaster. Moreover, the closer to the scene of actual operations, the more rational and organtzed the operation was defined as being. At least group personnel at a distance from organizational activities were more likely to think those operations were confused and disorganized.

7. There was a strong tendency for almost all organizations operating in the disaster area to concentrate on "ground zero", the point of maximum devastation. As it happened in this particular disaster, least assistance was needed there -- whether it was rescue or rehabilitation, communications, or transportation. It was the mountain localities around the reservoir, for instance, where the usual post-disaster assistance was needed more. Yet a conmunication line was not extended into that area until at least 36 hours or more after the disaster. Likewise, the fire groups did not systematically start moving down the river valley from the impact point to look for bodies until the fifth day.

In part, the concentration on "ground zero" was of course dictated by the physical terrain, the impact scene in the river valley being much easier to reach. In part, however, it seemed to stem from other factors. For instance, disaster headquarters -- to the extent that there was one -- was located on a small knoll almost at the geographic center of the devastated area instead of being out at the edge of the destruction or in one of the nearby undarnaged villages or towns. This had the incidental consequence of drawing visitors and sightseers right into the center of the area and tended to force them to go right through the teams of soldiers working at recovering bodies, stringing telephone lines, and rebuilding the road.

8. In the mobilization of organizations a relatively poor initial information feedback was partly counterbalanced by close adherence to standard operating procedures. No substantial body of information about the disaster -. even including such matters as its magnitude and the extent of the destruction -was wisely communicated outward from the disaster area for the first eight to ten hours. Yet, by the time information concerning what actually had occurred on the scene was relayed to the various higher headquarters, many of the organizations poised on the outer edges of the disaster area had rather fully mobilized. There had been, for instance, an extensive mobilization of medical facilities. In the city of Belluno alone, by daybreak the morning after the disaster, 1,000 bed hospital had been prepared, an Army field hospital in ten tents was set up, over 100 blood donors had been lined up, and large numbers of medical personnel of varying functions were assembled. Little of this kind of activity was improvised; almost all such organizational actions followed pre-disaster standard plans, although actual field operations often were highly improvised. 
Actually, along some lines at least, the absence of any real information fron the stricken area allowed organizations to adhere quite closely to their standby robilization plans, and to nove into a state of full readiness with a minimum of confusion and disorganization. For example, the relatively long time period between the first alert and detailed news allowed organizations to establish very extensive chains of communication running in some instances from a local sub-unit all the way back to the highest echelon in the top conmand in Rone. In fact, it seems doubtful if organizational nobilization could have proceeded as it did if adjustments had had to be continually improvised on the basis of fragmentary information trickling out of the disaster area.

To be sure, much of what was mobilized by organizations was not needed in this disaster. For instance, as earlier indicated, thousands and thousands of hospitals' beds had been prepared but there were only 86 injured survivors officially recorded. At worst, however, the organizational nobilization which occurred was non-functional for this sonewhat unusual disaster -- it was certainly not dysfunctional. On the other hand, when contrasted with mobilization, actual field operations frequently had an emergent quality, as we indicated in our earlier descriptions of group activities at the disaster site.

of interest were the comments of an Italian general who indirectly inplied that there might be some value in a slower but complete mobilization, over a nore rapid but inconplete organizational nobilization. He noted that sometimes there is a tendency to get involved in a situation too quickly and to respond to what is imediately present instead of standing off and attempting to assess the overall picture. He observed, of course, that this disaster in some ways allowed just such a delayed and broader view. Perhaps this observation stems from an old military maxim about comitting oneself too soon in a battle situation, but it does not seem totally irrelevant to the mobilization of organizations responding to a disaster.

9. The presence of the technical means of communication did not insure effective and accurate intra- or inter-organizational communications. 11 A telephone network linking all but the lake localities as well as special points such as the main commend post, the helicopter landing site, the headquarters of the fire companies, etc. was established by 9:00 A.M., or around ten hours after the disaster. However, observations by the DRC team as well as renarks of respondents indicated that even four days later there was not always rapid and accurate transmission of messages. The reasons for this are not clear although absence of a system of priority use for the limited number of available lines was probably a major factor as far as lack of speed was concerned. Both American and Italian military personnel reported a tendency for requests to be inaccurate (e.8., receiving a report that there were ten dead to be picked up at a certain place when there were only four bodies there, etc.). This, of course, complicated commend decisions since priorities for action were assigned on the basis of the information received. Such kinds of inforration seemed to have arisen at the point where non-organizational individuals introduced messages into the communication system rather than through the activity of the personnel manning the commication network. 
10. The lack of appropriate personnel was nore of a problem than the absence of any equipment. In the main, the Italian Army was able to obtain such light and heavy equipment as it needed for road building, debris clearance, and other engineering and related tasks. What specialized machines it did not have such as certain kinds of cranes were borrowed from Anerican Army units. In this sense, equipment needed for this kind of disester was not a problem. More of a problen was having enough trained personnel although comparatively speaking, this was a rather minor problem. Thus, the Italian military had more than enough bulldozers for all the tasks in which they were to be employed. These machines were literally available for the full twenty-four hours in $a$ day. However, as an Italian major pointed out, the same could not be said for trained men to run the machines. Soldiers with specialized skills could not labor the whole day round. Thus, the presence of a great deal of equipment as well as much personnel did not preclude a less than minimum use of the equipment because of a relative shortage of trained persons.

11. Certain situational contingencies ${ }^{12}$ permitted the use of particular fac11ities and personnel. Among these were the state of the weather and the location of the disaster site in relation to other areas. If these had been other than what they were, the post-disaster organizational operations would have assumed a somewhat different picture.

Although it had rained rather heavily in the days prior to the disaster, it did not do so in the week that followed. This was crucial, for anong other things, it permitted the American helicopters to fly and to carry ct: their missions which on some days totaled more than seventy-five. Not even the very skilled crews that ranned these ships could have collected bodies, evacuated villagers, transported supplies, etc., if the weather had been bad. Likewise, it is easy to visualize what major disruptions in operations would have occurred if the firemen had tried to recover and handle bodies in the rain, or if the Italian engineers had tried to build and pave a new valley road under similar weather conditions.

It was also fortunate that the disaster site was close to such a city as Belluno. It was close enough to the site to permit helicopters to use its modest but adequate airport. The nearness also facilitated some of the work of the provincial public health officials. In part, also, the presence of such a city nearby meant that facilities for arriving personnel -- whether newspaper personnel or civilian engineers or even relatives of the victins -- did not have to be specililly prepared or constructed on and about the disaster site itself.

12. In this situation there was an extreme manifestation of the typical convergence flow in a disaster (Fritz and Mathewson, 1957). There vas informal as well as a formal massive movement of personnel, information, and naterial into the impact areas. Making the massiveness of the influx even more conspicuous than usual was the handful of survivors in this particular disaster as compared with nost other disasters.

Particularly dysfunctional, at least from the viewpoint of organizational personnel on the scene, was the extremely high influx of VIPs, non-Italians as well as Italians. They often tied up transportation and took important 
officials away from their organizational tasks. In some instances, naturally, such visits were important for liaison, decision making, and general information to organizations both within and outside the disaster area. However, organizational personnel operating in the area, whether correctly or not, thought that there was an extremely high number of visitors who merely wanted to be able to say that they had been to the disaster scene.

Another noticeable feature which raised an interesting question -- often mentioned by organizational officials - was the progressively increasing influx of disaster relief supplies for survivors. Tons of clothing, bedding, and other kinds of material were shipped into the area by various groups both in Italy and elsewhere. Practically every major newspaper in Italy had launched a fund drive for the victims. The question raised, of course, was who would be the recipients of such help? Almost all persons who survived, including those around the major impact area, did not lose any of their material possessions. Even the migrant workers from Longarone and elsewhere who were away at the time of the disaster usually had many of their belongings with them. Thus, organizational personnel found it difficult to see to whom any large amounts of the arriving supplies and the accuralating money could possibly be given. It was initially believed that the influx would cease when it was finally perceived that very little in the way of such assistance was needed. However, national and international groups were just beginning to deliver their contributions two weeks after the disaster.

\section{Conclusions}

There are three general conclusions that can be drawn, two which are fairly explicit in the previous discussion, the other more implicit. It is clear that the prior historical situation, particularly the political context, strong influenced the response of most organizations. The role of the military can clearly be attributed to these factors. Many pre-impact or Time One factors carried over into the trans- and post-impact periods or Time Two, supporting the general proposition derived from disaster studies that there is considerabl: continuity in social behavior in the two time periods (Quarantel1i, 1977). On the other hand, in the face of perceived emergency needs which cannot be handled by past patterns, personnel and organizations act; they do not passively wait. Actions are undertaken even if new behaviors have to be developed. This is also supportive of general disaster findings that there is emergent social phenomena when the existing social structure cannot cope with a mass emergency (Quarantelli and Dynes, 1977a).

More implicit, since we have not made any direct comparisons, is that in a cross-cultural perspective, the Italian organizational responses are more similar to than different from American responses in similar situations. To be sure, there are some differences. In Italy, as compared with the United States, the military plays a more active part in disasters (see Anderson, 1969) more national planning for such eventualities appears to have occurred, organizations operate in a much more centralized social system, etc. However, on balance, there seems to be more similarities than differences in the 
organizational disaster responses in the two societies. (For a somewhat different point of view, however, see Mcluckie, 1977 who contrasted $\frac{1}{3}$ talian and United States responses in three different kinds of disasters). 13 


\section{FOOTNOTES}

1. Descriptive accounts of most of the disasters mentioned can be found in Cornel1 (1976)

2. The work of the Center is described in Dynes, Quarante11i and Taylor (1976). Examples of the research of the Center can be found in Quarante11i and Dynes (1970), Dynes, Quarantelli and Kreps (1972), Dynes and Quarante11i (1973), Dynes (1975), Quarantel1i (1977) and the September 1977 issue of Mass Emergencies edited by Taylor (1977).

3. All statistics, quotations and other details not attributed to specific sources are from the DRC files and generally refer to the situation as it was in 1963.

4. The only other published study on the Vaiont dam disaster of which we are aware is by Capraro (1974).

5. For a discussion of organizational problens in disasters see Barton (1970) and Quarante11i and Dynes (1977b).

6. Civilian-military relationships in Anerican disasters are discussed in Anderson (1968).

7. Political aspects of disasters have been alnost totally ignored in most studies undertaken (Quarante11i and Dynes, 1977a). See, however (Wettenha11 (1975).

8. Handling of many dead bodies is an unusual task and typically generates a conplex social response in disasters (See Hershiser and Quarantelli, 1976 and Blanshan 1977).

9. Inaccurate mass media accounts of disaster phenonene are frequently found in mass eraergencies in the United States (Quarante11i and Dynes, 1973, pp.非5)

10. This is also not unusual in American disasters (Quarantelli and Dynes, 1977b).

11: For general research findings on organizational connunication in disasters see Stallings (1971).

12. See Brouillette and Quarantelli (1971) for a discussion of situational factors in disasters.

13. The great need for cross-cultural studies in the disaster area are discussed in Taylor (fortheoning). 


\section{BIBLIOGRAPHY}

Anderson, Willian A.

1968

"Military-Civilian Relations During Disaster Operations." Report Series No. 5. Columbus, Ohio: Disaster Research Center, Ohio State University.

Anderson, William A.

1969

"Social Structure and the Role of the Military in Natural

Disasters." Sociology and Social Research 53: 242-253.

Barton, Allen H.

1970 Communities in Disaster: A Sociological Analysis of Collective Stress Situations. Garden City, New York: Anchor Books, Doubleday.

Besson, Pierre

1963 "Reflexions sur Longarone." Protection Civile et Industrialle. No. 114 December: $23-24,26$.

Blanshan, Sue A.

"A Time Model: Hospital Organizational Response to Disaster." Pp. 173-198 in E. L. Quarantelli (ed.), Disasters: Theory and Research. London: Sage Publications.

Brouillette, John R., and E. L. Quarantelli

1971 "Types of Patterned Variation in Bureaucratic Adaptations to Organizational Stress." Sociological Inquiry 41: 36-46.

Capraro, Guiseppe

1974 Longarone, 1963-1973: Demographic and Social Reconstruction. Unpublished Ph.D. dissertation. Rome: Pontifical Gregorian University School of Social Sciences.

Corne11, James

1976 The Great International Disaster Book. New York: Charles Scribner and Sons.

Doob, Leonard 1962

"South Tyrol: An Introduction to the Psychological Syndrome of Nationalism." Public Opinion Quarterly 26: 172-184.

Drabek, Thomas E. and E. L. Quarantelli

1967

"Scapegoats, Villains and Disasters." Trans-action 4: 12-17.

Dynes, Russe11 R.

1975 "The Comparative Study of Disaster: A Social Organizational Approach." Mass Emergencies 1: 21-31.

Dynes, Russell R. and E. L. Quarantelli 1973 "Editor's Introduction." American Behavioral Scientist 16: 305-311.

Dynes, Russell R., E. L. Ouarantelli and Gary A. Kreps

1972

"A Perspective on Disaster Planning." Report Series No. 11. Columbus, Ohio: Disaster Research Center, Ohio State University. 
Dynes, Russell R., E. L. Quarantelli and Verta A. Taylor

1976

"A Report on the Activities of the Disaster Research Center (DRC)". Miscellaneous Report No. 17. Columbus, Ohio: Disaster Research Center, Ohio State University.

Fritz, Charles E. and J. H. Mathewson

1957

"The Handing of the Dead in a Disaster." Omega 7, No. 3: 195-208.

McLuckie, Benjamin F.

1977

"Italy, Japan and the United States: Effects of Centralization on Disaster Response 1964-1969." Historical and Comparative Disasters Series No. 1. Columbus, Ohio: Disaster Research Center, Ohio State University.

Moore, Harry E., et al.

1963 Before the Wind: A Study of the Response to Hurricane Carla. Washington, National Academy of Sciences.

Quarantel1i, E. I.

1977 Disasters: Theory and Research. London: Sage Publications.

Quarantelli, E. L. and Russe11 R. Dynes

$1977 a$ "Different Types of Organizations in Disaster Responses and Their Operational Problems." Preliminary Paper No. 41. Columbus, Ohio: Disaster Research Center, Ohio State University.

Quarantel1i, E. L. and Russe11 R. Dynes

1977b "Response to Social Crisis and Disaster." Annual Review of Sociology 3: 23-49.

Quarante11i, E. L, and Russel1 R. Dynes (eds.)

"Urban Civil Disturbance: Organizational Change and Group Emergence." American Behavioral Scientist 16: 303-440.

Stallings, Robert A.

1971 "Communications in Natural Disasters." Report Series No. 10. Columbus, Ohio: Disaster Research Center, Ohio State University.

Taylor, Verta A. (ed.)

1977 The Delivery of Energency Medical Services. Mass Energencies 2, No. 3. (special issue)

Taylor, Verta A.

forthcoming Some Needed Cross-cultural Studies of Disaster Behavior.

Wettenhall, R. L.

1975 Bushfire Disaster: An Australian Community of Crisis, Sydney, Australia: Argus, Roberson. 